Original Research Paper

\title{
Struktur Komunitas Kupu-Kupu di Taman Wisata Alam Suranadi, Lombok Barat
}

\author{
M. Liwa Ilhamdi ${ }^{1 *}$, Agil Al Idrus ${ }^{1}$, Didik Santoso ${ }^{1}$ \\ ${ }^{1}$ Program Studi Pendidikan Biologi PMIPA FKIP Universitas Mataram, Mataram, Indonesia
}

\author{
Article history \\ Received : 13 November 2018 \\ Revised : 22 Mei 2019 \\ Accepted : 10 Juli 2019 \\ Published : 14 Agustus 2019 \\ *Corresponding Author: \\ M. Liwa Ilhamdi, \\ Program Studi Pendidikan \\ Biologi PMIPA FKIP \\ Universitas Mataram, Mataram, \\ Indonesia \\ Email: \\ liwa_ilhamdi@unram.ac.id
}

\begin{abstract}
Abstrak : Taman Wisata Alam Suranadi merupakan satu dari 11 kawasan konservasi di Nusa Tenggara Barat. Penelitian ini merupakan penelitian deskriptif eksploratif dengan tujuan untuk mengetahui struktur komunitas kupu-kupu di TWA Suranadi Lombok Barat.Pengambilan data dilakukan sebanyak 4 kali pengulangan dalam waktu 2 bulan (April - Mei 2017) pada pagi dan sore hari. Metode pengambilan data menggunakan metode survei dengan teknik sweeping net mengikuti empat jalur pengamatan yakni jalur tepi kiri hutan, jalur tepi kanan hutan, jalur tengah dan jalur air. Hasil penelitian menunjukkan 5 famili kupu-kupu ditemukan di TWA Suranasi (Nymphalidae, Pieridae, Lycaenidae, Papilionidae dan Hesperiidae). Nymphalidae merupakan famili yang memiliki proporsi terbesar dari total proporsi kupu-kupu di TWA Suranadi yakni 35,7\% sedangkan proporsi terendah yakni family Hesperiidae (0,9\%).Proporsi famili kupu-kupu pada masing-masing jalur ditemukan berbeda. Famili Nymphalidae ditemukan memiliki proporsi tinggi pada dua jalur berbeda yakni jalur kiri $(35,3 \%)$ dan kanan $(37,0 \%)$, sedangkan pada jalur air proporsi tertinggi dimiliki oleh Papilionidae $(34,1 \%)$, dan Pieridae $(50,0 \%)$ pada jalur tengah. Proporsi terendah dimiliki oleh dua famili yakni famili Hesperiidae pada tiga jalur yakni 0,7\% (kiri) $1,0 \%$ (kanan), tengah $(2,1 \%)$, dan famili Lycaenidae $(17,1 \%)$ pada jalur air. Struktur komunitas kupu-kupu berbeda-beda tiap jalur pengamatan karena perbedan karakteristik habitat di Taman Wisata Alam Suranadi.
\end{abstract}

Kata kunci : Struktur Komunitas, Kupu-kupu, TWA Suranadi

Abstract : Suranadi natural park is one of 11 conservation area in West Nusa Tenggara.This research is an explorative descriptive study with aim to know the structure of the Butterfly community in Suranadi Natural Park, West Lombok. Data retrieval is done in 4 repetitions within 2 months (April-May 2017) in the morning and evening. The method of data collection uses a survey method with sweeping net techniques following four observation paths; first, the left edge of the forest. Second, right edge of the forest, third, middle lane and the last is waterway. The result of the study showed 5 families of butterflies are found in Suranadi Natural Park (Nymphalidae, Pieridae, Lycaenidae, Papilionidae dan Hesperiidae). Nymphalidae is the family that has the largest proportion $(35.7 \%)$ of the total proportion of butterflies in Suranadi Natural park, while the lowest proporstion is the Hesperidae $(0.9 \%)$. The different proportion of Butterflies families was found in each parth. Nymphalidae family was found highest proportion on two lines; left line (35.3\%) and right line $(37.0 \%)$, whereas in waterway, the high proportion was owned by Papilionidae $(34.1 \%)$ and Pieridae $(50.0 \%)$ in Middle line. The lowest proportion is owned by two families; Hesperidae family on three lines ( left $(0.7 \%)$, Right $(1.0 \%)$, and middle (2.1\%)) and Lycanidae on waterway (17.1\%). The structure of the Butterfly community difference of each path due to differences in habitat characteristics.

Keywords : Community Structure, Butterfly, TWA Suranadi 


\section{Pendahuluan}

Kupu-kupu (Lepidoptera) merupakan salah satu keanekaragaman hayati Indonesia yang memiliki jumlah jenis yang cukup banyak. Diperkirakan terdapat 2200 jenis kupu-kupu ditemukan di Indonesia. Tercatat 1000 jenis kupu-kupu ditemukan di Pulau Sumatera, 600 jenis ditemukan jawa dan bali (Soekardi, 2007). Tingginya jumlah jenis kupu-kupu yang ditemukan menjadi salah salah satu penyokong keanekeragaman fauna di Indonesia sehingga dikenal dengan megabiodiversity (Mittermeier et al., 1997). Sulistyani (2013) menyatakan jenis kupu-kupu endemik yang ditemukan di Indonesia mencapai $50 \%$. Sehingga peranan pemerintah dalam menyediakan kawasan perlindungan untuk menjaga keanekaragaman hayati seperti Taman Wisata Alam, Taman Nasional, Cagar Alam, Kawasan Konservasi, dan kawasan perlindungan lainya sangat di perlukan.

Salah satu kawasan perlindungan yang ada di Indonesia adalah Taman Wisata Alam Suranadi. Kawasan ini merupakan salah satu dari 11 Taman Wisata Alam yang dikembangkan oleh BKSDA Propinsi NTB yang secara administrasi berada di Desa Suranadi, Kecamatan Narmada, Kabupaten Lombok Barat. Kawasan hutan ini memiliki luas $52 \mathrm{Ha}$ dan ditetapkan sebagai kawasan Taman Wisata Alam sesuai Keputusan Menteri Pertanian No. 646/Kpts/Um/10/76, tgl 15 Okt 1976 jo No.274/Kpts/Um/5/77, tgl 30 Mei 1997. Jasa lingkungan yang disediakan kawasan hutan tersebut berupa jasa dalam mengatur tata air (hidrologi), penyerap dan penyimpan karbon, wisata alam, keanekaragaman hayati dan lain-lain (Rahadi et al., 2015).

Hutan Suranadi dikategorikan sebagai salah satu kawasan yang memiliki keunikan secara bioekologi karena menyediakan tempat hidup (habitat) bagi berbagai jenis kupu-kupu. Hasil penelitian sebelumnya yang dilakukan Linda (2013) merekomendasikan untuk melakukan survei lanjutan tentang kupu-kupu yang ada di kawasan itu. Hal ini diperlukan karena masih minimnya data kupu-kupu terutama yang terkait dengan struktur komunitas, distribusi kupu-kupu untuk kepentingan sumber belajar dan ekowisata.

Hutan Wisata Suranadi terletak di Kecamatan Narmada, Kabupaten Lombok Barat, Provinsi Nusa Tenggara Barat, ditetapkan sebagai Taman Wisata Alam dengan luas 52 ha. Berdasarkan SK Mentri Pertanian tanggal 15 Oktober 1976 Nomor: 274/Kpts/UM/5/77 guna meningkatkan fungsi konservasi baik flora, fauna maupun ekosistemnya, agar tercapai keserasian lingkungan dan dimanfaatkan sebagai obyek reaksi, pendidikan, kebudayaan, penelitian dan kepariwisataan (Rohayuni, 2002).

Menurut klasifikasi Schmidt-Ferguson (dalam Wahyuni, 2010), Taman Wisata Alam Suranadi memiliki tipe iklim D dengan curah hujan rata-rata antara $1500 \mathrm{~s} / \mathrm{d} 2000 \mathrm{~mm}$ per tahun, hujan turun antara bulan Oktober sampai April. Temperatur minimum $22,2^{\circ} \mathrm{C}$, dan temperatur maksimum $36,9^{\circ} \mathrm{C}$.

Tipe vegetasi yang menutupi HWA Suranadi merupakan vegetasi campuran yang tersebar merata dan ditandai dengan tumbuhnya pohon-pohon yang tinggi bercampur dengan perdu dan semak sehingga secara keseluruhan membentuk lapisan-lapisan tajuk tertutup. Jenis flora yang terdapat di HWA Suranadi antara lain Beringin (Ficus sp), Garu (Disoxilum sp), Terep (Arthocarpus elastica), Suren (Toona sureni), Kemiri (Aleurites moluccana), Purut (Parathocarpus venenoosa), Pulai (Alstonia scholaris) dan lain-lain. Jenis satwa yang ada di HWA Suranadi didominasi oleh Kera abu-abu (Macaca fascicularis) serta beraneka ragam kupu-kupu serta kupu-kupu, misalnya Papilio helenus, Papilio memnon, Graphium sarpedon, Polyura athamas, dan lain-lain. Di kawasan ini juga dapat disaksikan fenomena ekologi yang sangat menarik berupa berbagai macam bentuk simbiosis tumbuhan dari sekedar simbiosis menumpang seperti tumbuhan merambat (liana) sampai dengan strangler (mencekik) seperti yang terjadi pada pohon Pulai (Alstonia scholaris) dan Beringin (Ficus benjamina). Fenomena ini menjadikan kawasan HWA Suranadi cocok untuk kegiatan wisata pendidikan (Wahyuni, 2010).

Kupu-kupu di TWA Suranadi merupakan salah satu kekayaan hayati yang memiliki nilai keindahan, ekologi, ekonomi, penelitian, kualitas lingkungan yang menunjang ekowisata. Pemetaan distribusi dan keanekeragaman kupu-kupu penting sebagai bahan pembelajaran IPA yang berasal dari hasil penelitian.

Keberadaan jenis kupu- kupu berbeda di setiap tempat. Hal ini dipengaruhi oleh banyak faktor diantaranya jenis tanaman, udara yang bersih, dan pencahayaan yang cukup. Kerusakan alam seperti berubahnya fungsi areal hutan, sawah, dan perkebunan yang menjadi habitat bagi kupu-kupu, dapat menyebabkan penurunan jumlah maupun jenis kupu-kupu di alam (Amir, 1995).

Penyebaran kupu-kupu dapat memberikan informasi yang baik dalam studi lingkungan sebagai indikator lingkungan, serta perubahan yang lingkungan yang mungkin terjadi. Kupu-kupu juga memberi andil yang sangat berarti dalam mempertahankan keseimbangan alam dengan bertindak sebagai penyerbuk pada bunga bersama hewan penyerbuk lainnya (Amir, 1993).

Kupu-kupu bermanfaat dalam kehidupan manusia, seperti estetika atau keindahan, pendapatan ekonomi, penelitian, petunjuk mutu lingkungan, dan penyebaran tumbuhan. Selain itu keberadaan kupukupu tidak terlepas dari daya dukung habitatnya, yakni habitat yang memiliki penutupan vegetasi perdu dan pohon yang berakar kuat, serta adanya sungaisungai yang mengalir. Salah satu hutan yang banyak ditemukan kupu-kupu adalah hutan Suranadi. Hutan Suranadi ditetapkan sebagai Taman Wisata Alam dengan luas 52 ha berdasarkan SK Mentri Pertanian tanggal 15 Oktober 1976 Nomor: 274/Kpts/UM/5/77. 
Linda (2013) menemukan kupu-kupu di Hutan Wisata Alam Suranadi 28 jenis dan 404 individu kupu-kupu yang termasuk ke dalam 6 famili yaitu 6 jenis dari famili Papilionoidae, 11 jenis dari famili Nymphalidae, 3 jenis dari famili Danaidae, 4 jenis dari famili Pieridae, 2 jenis dari famili Lycaenidae, dan 1 jenis dari famili Hesperiidae. Keberadaan kupu-kupu di kawasan hutan wisata alam Suranadi tidak terlepas dari daya dukung habitatnya yang memiliki penutupan vegetasi perdu dan pohon yang berakar kuat, serta adanya sungai-sungai yang mengalir.

Belum banyak data hasil kajian tentang kupukupu di kawasan TWA Suranadi. Penelitian sebelumnya menemukan 28 jenis kupu-kupu di TWA Suranadi yang termasuk ke dalam enam famili yaitu Papilionoidae, Nymphalidae, Danaidae, Pieridae, Lycaenidae, danHesperiidae (Ariani, et al 2013).Sedangkan Nugroho (2017)memperoleh 60 spesies kupu-kupuyang tergolong dalam 5 famili.

Kupu-kupu memiliki nilai penting bagi manusia maupun lingkungan antara lain, nilai ekonomi, ekologi, estetika, pendidikan, konservasi dan budaya (Lamatoa et al, 2013). Kupu-kupu memiliki peranan yang sangat penting sebagai pollinator dan dapat dijadikan sebagai bioindikator terhadap perubahan kualitas lingkungan (Lestari, et al., 2015). Fungsi kupu-kupu yaitu sebagai polinator yang membantu terjadinya polinasi pada bunga-bunga sehingga reproduksi tumbuhan dapat berlangsung dengan baik. Selain itu, di dalam ekosistem, kupukupu merupakan penyedia makanan karena perannya sebagai herbivora dan juga sumber makanan bagi hewan-hewan karnivora (Soekardi et al., 2015).

Berkaitan dengan sedikitnya data tentang kupu-kupu sehingga belum memadai untuk dikembangkan menjadi dasar yang baik dalam membuat kegiatan untuk mengkonservasi kupu-kupu. Karena itu diperlukan penelitian lebih lanjut untuk melengkapi data-data yang ada sebelumnya sehingga memberikan justifikasi yang benar dalam mengembangkan kegiatan-kegiatan konservasi yang ada di Hutan Wisata alam Suranadi pada masa-masa yang akan datang.

Informasi yang hanya terpusat pada data jumlah jenis kupu-kupu yang ditemukan tanpa memperkuat informasi tentang distribusi serta dugaan kondisi populasi tiap jenis kupu-kupu yang ditemukan hanya memberikan informasi-informasi yang bersifat mendasar. Informasi mengenai distribusi kupu-kupu di Hutan wisata alam Suranadi dapat menunjukkan pola persebaran kupu-kupu, sedangkan informasi tentang dugaan populasi tiap jenis kupu-kupu yang ditemukan dapat memberikan informasi tentang status kelangkaan kupu-kupunya. Kedua jenis informasi tersebut dapat menjadi informasi yang sangat esensial dalam membuat suatu rumusan kebijakan dalam mengembangkan kegiatan-kegiatan konservasi untuk melakukan kegiatan pengelolaan kupu-kupu yang ada di hutan wisata alam Suranadi.
Berdasarkan pentingnya peranan kupu-kupu dalam ekosistem maka penelitian mengenai struktur komunitas kupu-kupu di kawasan TWA Suranadi menjadi penting untuk dilakukan sehingga kedepannya dapat dipergunakan sebagai pertimbangan dalam pengelolaan dan pengembangan kawasan TWA Suranadi.

\section{Bahan dan Metode}

Penelitian ini dilaksanakan pada bulan April sampai Mei 2017 di Taman Wisata Alam Suranadi Lombok Barat. Proses pengambilan data dalam penelitian ini menggunakan metode survei langsung. Penangkapan kupu-kupu dilakukan dengan teknik sweeping net di sepanjang jalur pengamatan yang telah ditentukan berdasarkan hasil observasi. Sampel kupu-kupu yang diambil dalam penelitian ini adalah kupu-kupu dewasa. Pengambilan sampel dilakukan pada sepanjang masing-masing jalur dengan menggunakan jaring serangga. Pengambilan data dilakukan sebanyak 4 kali pengulangan dalam waktu 2 bulan. Penangkapan kupu-kupu dilakukan pada pagi hari mulai pukul 08.00 - 11. 00 WITA dan sore hari mulai pukul $15.00-17.00$ WITA.

Kupu-kupuyang tertangkap di lapangan sebagai sampel diawetkan dengan cara menyuntikkan larutan formalin4\% di bagian thoraknya menggunakan alat suntik kemudian disimpan menggunakan kertas papilot (Ilhamdi, 2018). Sampel kemudian diidentifikasi di laboratorium Biologi FKIP Universitas Mataram dan dihitung jumlah individunya. Sampel kupu-kupu diidentifikasi menggunakan buku Panduan Praktis Kupu-kupu di Kebun Raya Bogor (Peggie dan Amir, 2006)dan Panduan Lapangan Kupu-Kupu di TWA Kerandangan (Wahyuni dan Fatahullah, 2015).Data jenis dan jumlah individu jenis yang ditemukan digunakan untuk menentukan proporsi famili kupukupu dalam bentuk kerapatan relatif secara umum dan pada masing-masing jalur pengamatan di TWA Suranadi.rumus kerapatan relatif mengacu pada Kreb (2009):

$$
\mathrm{KR}=(\mathrm{ni} / \mathrm{N}) \times 100 \%
$$

dimana,

$$
\begin{array}{ll}
\text { KR } & \text { : Kerapatan relatif spesies } \\
\text { ni } & \text { : jumlah individu spesies-i } \\
\mathrm{N} & \text { : total jumlah individu. }
\end{array}
$$

\section{Hasil dan Pembahasan}

Berdasarkan hasil penelitin ini ditemukan 569 individu yang terdiri atas 40 jenis dan termasuk ke dalam 5 Famili kupu-kupu di kawasan TWA Suranadi (Gambar 1). Proporsi famili tertinggi yang ditemukan adalah Nymphalidae $(35,7 \%)$ kemudian diikuti oleh famili Pieridae (29,9\%), Lycaenidae (17,8\%), Papilionidae (15,8\%) dan Hesperiidae (0,9\%). Jumlah famili yang ditemukan di TWA Suranadi lebih tinggi bila dibandikan pada daerah lainnya. Florida et al. 
(2015) menemukan 15 jenis dari 3 famili kupu-kupu di Cagar Alam Mandor Kalimantan Barat dengan 7 jenisnya berasal dari famili Nymphalidae.Famili Nymphalidae merupakan famili kupu-kupu yang umum ditemukan dalam jumlah jenis dan individu terbanyak di Indonesia. Dari 15 jenis kupu-kupu yang ditemukan di Cagar Alam Mandor Kalimantan Barat, 7 jenisnya berasal dari famili Nymphalidae (Florida et al., 2015). Septianella et al. (2015) juga menemukan total 45 jenis kupu-kupu, 26 jenis diantaranya berasal dari Famili Nymphalidae di Desa Pasirlangu, Bandung Barat. Hal serupa juga dilaporkan oleh Lestari et al. (2015) yang menemukan 15 jenis kupukupu yang 46,7\% diantaranya berasal dari Famili Nymphalidae.

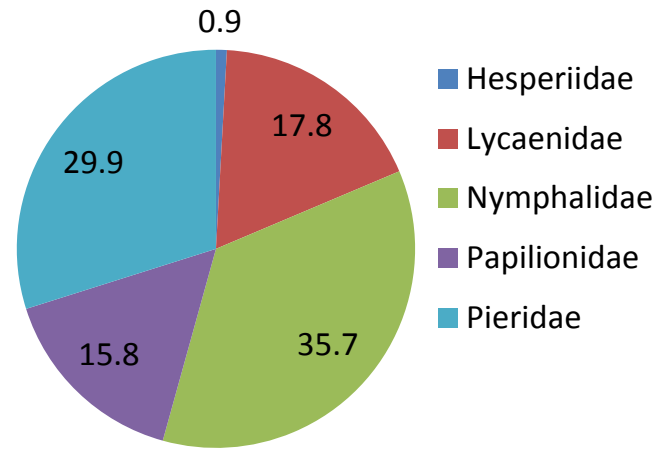

Ggambar 1. Proporsi famili kupu-kupu yang ditemukan di TWA Suranadi

Famili Nymphalidae merupakan famili kupukupu dengan jumlah spesies terbesar di dunia dibandingkan famili lainnya yaitu sekitar 6.500 spesies (Vane-Wrught dan de Jong 2003). Famili Nymphalidae memiliki kecenderungan bersifat polifag (mempunyai jenis makanan lebih dari satu macam). Sifat polyfag ini sangat memungkinkan famili Nymphalidae tetap dapat memenuhi kebutuhan makannya meskipun tumbuhan inang utamanya tidak tersedia (Lestari et al., 2015). Kondisi inilah yang disinyalir menjadi penyebab famili Nymphalidae dapat dijumpai dalam jumlah jenis dan individu yang cukup besar pada masing-masing jalur pengamatan di TWA Suranadi. Peggie dan Amir (2006) menambahkan bahwa famili tumbuhan yang dijadikan sumber pakan kupu-kupu dari famili Nymphalidae adalah Arecaceae, Musaceae, dan Poaceae yang banyak ditemukan di lokasi penelitian.

Jumlah famili yang ditemukan berbeda-beda pada masing-masing jalur pengamatan. Gambar 2 menunjukkan bahwa proporsi famili tertinggi pada jalur kiri adalah Nymphalidae (35,3\%) kemudian diikuti oleh famili Lycaenidae $(25,4 \%)$, Pieridae $(23,9 \%)$, Papilionidae (14,7\%) dan Hesperiidae $(0,7 \%)$. Hal serupa juga ditemukan pada jalur kanan dimana famili Nymphlidae juga ditemukan dominan yaitu $37,0 \%$, kemudian diikuti oleh Pieridae $(34,6 \%)$, Lycaenidae $(11,1 \%)$, Papilionidae $(16,3 \%)$ dan Hesperiidae $(1,0 \%)$. Kesamaan ini diduga karena jalur kiri dan jalur kanan memiliki karakteristik lingkungan yang serupa. Jalur ini merupakan jalur tepian hutan yang berbatasan langsung dengan perkebunan masyarakat. Jalur ini memiliki kondisi vegetasi dan kondisi lingkungan fisik yang tidak jauh berbeda sehingga sangat mungkin jika famili kupu-kupu yang ditemukan relatif sama.

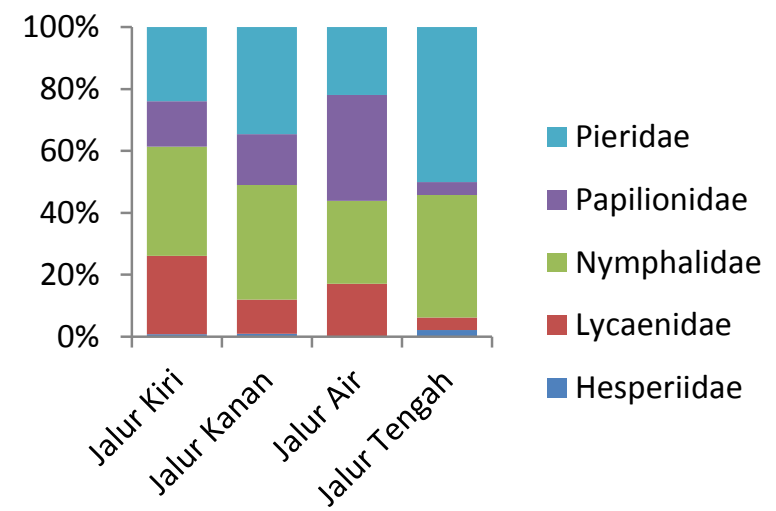

Gambar 2. Perbandingan proporsi famili kupu-kupu yang ditemukan pada masing-masing jalur pegamatan

Koneri \& Saroyo (2011) juga menemukan kekayaan dan keanekaragaman jenis kupu-kupu di Hutan Lindung Gunung Klabat, Sulawesi Utara tertinggi pada habitat kebun dan berbeda nyata dengan habitat lainnya. Hal ini terkait dengan keberadaan tumbuhan inang dan sumber makanan bagi kupukupu. Thomas et al. (2004) menyatakan bahwa banyaknya spesies kupu-kupu sangat tergantung pada tumbuhan dan nektar sebagai sumber makanan. Semakin banyak sumber makanan dalam suatu daerah, maka keberadaan kupu-kupu akan semakin melimpah.

Walaupun secara umum kupu-kupu yang ditemukan di TWA Suranadi didominasi oleh famili Nymphalidae namun hal berbeda ditemukan pada jalur air dan jalur tengah dimana proporsi famili yang terbesar pada jalur ini adalah Papilionidae $(34,1 \%)$ kemudian diikuti oleh Nymphlidae $(26,8 \%)$, Pieridae $(22,0 \%)$, Lycaenidae $(17,1 \%)$. Jalur air memiliki kelembaban dan intensitas cahaya yang relatif lebih tinggi dibandingkan jalur lainnya. Hal ini disebabkan oleh adanya aliran air dan bukaan kanopi menyebabkan jalur ini menjadi cukup terang. Kupukupu yang dominan ditemukan pada daerah ini adalah jenis yang memiliki kemampuan terbang tinggi seperti jenis yang berasal dari famili Papilionidae. Walaupun memiliki intensitas cahaya yang tinggi, namun diikuti oleh kelembaban yang lebih lebih tinggi dibandingkan dengan jalur lainnya sehingga berpengaruh pada keberadaa kupu-kupu yang menggunakan jalur tersebut sebagai habitat. Kelembaban pada jalur ini masih dalam rentang toleransi aktivitas kupu-kupu. Braby (2004) menjelaskan bahwa kupu-kupu tidak dapat hidup pada kelembaban yang sangat tinggi $(>90 \%)$. 
Proporsi yang berbeda juga ditemukan pada jalur tengah, kupu-kupu dari famili Pieridae memiliki proporsi trtinggi $(50,0 \%)$ kemudian diikuti oleh Nymphalidae (39,6\%), Papilionidae (4,2\%), Lycaenidae $(4,2 \%)$ dan Hesperiidae $(2,1 \%)$. Jalur ini memiliki kondisi lingkungan yang berbeda dengan jalur lainnya. Tutupan dan kelembaban yang relatif lebih tinggi dibanding dengan jalur lainnya disinyalir menjadi penyebab berbedanya proporsi famili kupukupu yang ditemukan. Famili Pieridae memiliki kelimpahan yang tinggi karena pada umumnya bersifat polifagus dan tersedianya sumber makanan (food plant) serta pohon inang (host plant) sebagai sumber makanan dan tempat untuk meletakan telurnya (Effendi, 2009). Peggie dan Amir (2006) menjelaskan bahwa Caesalpiniacea (Cassia, Senna, Bauhinia, Brownea), Capparaceae (Crateva), Papilionaceae (Butea, Pterocarpus, Sesbania) merupakan tanaman inang bagi beberapa jenis dari kupu-kupu Pieridae. Vane-Wright dan De Jong (2003) menambahkan bahwa sumber pakan larva dari famili Pieridae sebagian besar berasal dari famili Asteraceae, Brassicaseae, Capparaceae, Fabaceae, Loranthaceae, Rhamnaceae, Santalaceae, Zygophyllaceae dan Coniferales. Jenis tumbuhan tersebut juga ditemukan di jalur ini.

Keberadaan spesies kupu-kupu sangat dipengaruhi oleh kondisi vegetasi, faktor lingkungan dan gangguan manusia. Perubahan pada vegetasi dan lingkungan akan berdampak pada komposisi spesies kupu-kupu. Adapun proporsi spesies kupu-kupu yang ditemukan di TWA Suranadi. Nymphalidae merupakan famili yang memiliki proporsi spesies terbanyak yakni $45 \%$ diikuti oleh Pieridae 25\%, Papilionidae $15 \%$, Lycaenidae $13 \%$ dan Hesperiidae $2 \%$.

Jumlah spesies kupu-kupu yang ditemukan di TWA Suranadi lebih sedikit bila dibandingkan dengan lokasi lainnya di luar Pulau Lombok. Sari (2013) menemukan 95 spesies yang termasuk ke dalam 5 famili di Kawasan Wisata Alam Lembah Cilengkrang Taman Nasional Gunung Ciremai, 43 spesies (6 famili) di Hutan Kota Muhammad Sabki Kota Jambi (Rahayu, 2012), 60 spesies (5 famili) di kawasan wisata Hapanasan Rokan Hulu Riau (Febrita, 2014), dan 45 spesies ditemukan di Pantai Utara Manokwari Papua Barat (Hermawanto, 2016).

Sihombing (2002) menyatakan bahwa kupukupu biasanya hidup pada habitat terestrial tetapi komposisi dari spesies yang ada bervariasi menurut kondisi habitatnya. Habitat kupu-kupu ditandai dengan tersedianya tumbuhan inang untuk pakan larva, serta tumbuhan penghasil nektar bagi imagonya. Apabila kedua tumbuhan ini tersedia di suatu habitat, maka memungkinkan kupu-kupu dapat melangsungkan hidupnya. Bila hanya salah satunya saja yang tersedia, maka kupu-kupu tidak dapat melangsungkan kehidupannya (Soekardi, 2007). Disamping itu, juga diperlukan faktor cahaya yang cukup, udara yang bersih, dan air sebagai materi yang dibutuhkan untuk menjaga kelembaban lingkungan tempat kupu-kupu tersebut hidup.

Proporsi jumlah individu masing-masing famili kupu-kupu yang ditemukan di TWA Suranadi terbesar adalah Nymphalidae (35\%) kemudian diikuti oleh Pieridae (30\%), Lycaenidae (18\%), Papilionidae (16\%) dan Hesperiidae (1\%). Dominansi kupu-kupu famili Nymphalidae merupakan pola yang umum dijumpai pada berbagai tempat. Selain memiliki keanekaragaman spesies yang tinggi, famili Nymphalidae juga memiliki sebaran yang luas dan tingkat kelimpahan yang lebih tinggi dibandingkan famili lainnya. Nymphalidae pada umumnya menyukai tempat seperti hutan, daerah terang dan ladang (Salmah et al., 2012).

Variasi kanopi berdampak pada perbedaan daya tembus cahaya matahari ke setiap bagian hutan sehingga kondisi habitat menjadi beragam. Jalur kanan dan jalur kiri merupakan tepian hutan sekunder yang berbatasan langsung dengan perkebunan masyarakat sehingga memiliki kanopi yang cukup terbuka. Keberadaan ladang dan kebun bunga masyarakat menyediakan sumber makanan yang menarik bagi kupu-kupu sehingga banyak spesies yang terkonsentrasi di lokasi tersebut. Berbeda halnya dengan jalur tengah yang memiliki kanopi yang cukup padat sehingga menghalangi penetrasi cahaya matahari yang berdampak pada lebih sedikitnya spesies kupu-kupu yang ditemukan.

Habitat kupu-kupu hasil interaksi antara komponen biotik dan abiotik, komponen-komponen tersebut saling berinteraksi membentuk hubungan yang saling mempengaruhi. Bila hanya salah satunya saja yang tersedia, maka kupu-kupu tidak dapat melangsungkan kehidupannya, apalagi jika tumbuhan inangnya tidak ada. Habitat kupu-kupu adalah tempat lembab yang memiliki banyak vegetasi bunga, badanbadan perairan dan banyak mendapat sinar matahari. Sebagian besar jenis hidup di areal pertanian, kebun buah, hutan primer dan sekunder (Sihombing 2002). Lepidoptera tersebar dari dataran rendah sampai ketinggian 750 mdlp, bahkan ada yang dapat hidup sampai pada ketinggian $2.000 \mathrm{mdpl}$ (Sihombing, 2002).

Kupu-kupu dari Famili Papilionoidea, sangat menyukai cahaya. Cahaya diperlukan untuk mengeringkan sayap kupu-kupu pada saat keluar dari kepompong. Cahaya akan memberikan energi panas kepada tubuh, sehingga suhu tubuh meningkat dan metabolisme menjadi lebih cepat. Peningkatan suhu tubuh akan mempercepat perkembangan larva kupukupu (Suantara, 2000). Keberadaan Troides helena dan beberapa jenis kupu-kupu lain, khususnya dari famili Papilionidae ini mulai terancam punah di alam, karena diburu manusia untuk diperdagangkan, ataupun karena penurunan kualitas habitat kupu-kupu di alam. Jenis Troides helena banyak diburu karena keindahan maupun kelangkaannya (Noerdjito dan Aswari, 2003; Nurjannah, 2010). Keberadan kupukupu Troides helena ini dipengaruhi oleh adanya 
pakan dan tanaman inangnya yaitu tumbuhan Aristolochia tagala famili Aristolochiae.

Troides helena ditemukan di jalur air dengan letak posisi antara G1-G6 dan hanya dijumpai pada saat pengambilan sampel ketiga. Hal ini berkaitan dengan periode terbang kupu-kupu dan kemungkinan dekat dengan tanaman inangnya. Menurut Peggie dan Amir (2006) pengamatan pada waktu yang berbeda mungkin akan menunjukkan jenis yang berbeda karena jenis-jenis tersebut mempunyai periode terbang yang berbeda. Hal ini jelas sekali di daerah 4 musim. Di Indonesia juga terdapat perbedaan dalam distribusi dan keanekaragaman kupu-kupu di musim penghujan dan di musim kemarau.

Pupulasi Troides helena di hutan sekunder TWA Suranadi terbilang sedikit. Kondisi ini dapat mengancam keberlangsungan hidup Troides helena, karena disamping tumbuhan inang yang langka, kemampuan berkembang biak jenis ini tergolong rendah. Troides helena berukuran besar, telur yang dihasilkan sedikit, dan waktu reproduksinya cukup lama. Berdasarkan penelitian Nurjannah (2010), Troides helena menghasilkan 35-150 butir telur, dan tingkat keberhasilan hingga fase imago hanya 8-12\%. Kondisi ini menyebabkan jumlah individu Troides helena sedikit dan frekuensi pertemuan dengan imagonya jarang. Fenomena tersebut menunjukkan bahwa kawasan taman wisata alam ini perlu dilestarikan. Populasi kupu-kupu yang terbatas di alam, dan kepekaannya yang tinggi terhadap gangguan menyebabkan apabila lingkungannya terganggu, kelangsungan hidupnya akan terancam, bahkan menyebabkan kepunahan kupu-kupu di tempatnya.

\section{Kesimpulan}

Berdasarkan hasil pengamatan dan pembahasan maka dapat disimpulkan bahwa ditemukan 5 Famili kupu-kupu di TWA Suranadi. Nymphalidae merupakan Famili yang memiliki proporsi terbesar secara total dan berdasarkan jalur dominan di jalur kiri dan kanan hutan, sedangkan pada jalur air proporsi tertinggi dimiliki oleh Papilionida, dan Pieridae pada jalur tengah hutan. Sementara, proporsi terendah di miliki oleh dua famili yakni family Hesperiidae pada tiga jalur yakni kiri, kanan, serta tengah, dan famili Lycaenidae (pada jalur air).

\section{Ucapan Terima kasih}

Penulis menyampaikan terima kasih kepada TWA Suranadi yang telah memberikan ijin untuk melakukan penelitian di dalam Kawasan, Direktorat Riset dan Pengabdian Masyarakat, Kemenristekdikti yang telah membiayai penelitian produk terapan di tahun 2017, serta ungkapan terima kasih juga disampaikan kepada tim Berugak Organik Narmada: Rizky Regina Kawirian, Gde Cahyadi Wirajagat,
Noar Muda Satyawan, Irmayani, Sumiati, Rubiyatna Sakaroni dan Siti Khusnul Khotimah.

\section{Daftar Pustaka}

Amir, M. (1995). Кири-kири Indonesia, Permasalahan dan Pelaksanaan Pelestariannya. Jurnal Duta Rimba, Edisi September-Oktober, 51-55.

Amir, M., Noerdjito, A. \& Ubaidillah, R. 1993. Butterflies of Batimurung, South Sulawesi. International Butterfly Conference. Ujung Pandang. Indonesia. (online): http: //www.smallcrab.com/others/35-lainlain/69-kunang-kunang, Diakses tanggal 9 Juni 2019.

Ariani, L., Artayasa \& Ilhamdi, L. (2013). Keanekaragaman dan distribusi kupu-kupu di HutanSuranadi sebagai media pembelajaran Biologi,Proseding Seminar Nasional, Pascasarjana Magister Pendidikan IPA, Universitas Mataram.

Braby, M.F. (2004). The Complete Fiield Guide to Butterflies of Australia. Collinwood: CSIRO Publising

Effendi AM. (2009). Keragaman Kupu-kupu (Lepidoptera: ditrysia) di kawasan "hutan koridor" Taman Nasional gunung Halimun Salak Jawa Barat. [tesis] Institut Pertanian Bogor, Bogor.

Febrita, E., Yustina \& Dahmania. (2014). Keanekaragaman jenis kupu-kupu (subordo rhopalocera) di kawasan wisata hapanasan rokan hulu sebagai sumber belajar pada konsep keanekaragaman hayati. Jurnal biogenesis, 10 (2)

Florida M, Setyawati TR \& Yanti AH. (2015). Inventarisasi Jenis Kupu-Kupu pada Hutan Kerangas di Kawasan Cagar Alam Mandor Kabupaten Landak. Jurnal Protobiont, 4 (1) : 260-265

Hermawanto, R., Rawati, P. \& Sepus, F. (2015). Kupu-kupu (Papilionoidea) di Pantai Utara Manokwari, Papua Barat: Jenis, keanekaragaman dan pola distribusi. Prosiding Seminar Seminar Nasional Masyarakat Biodiversitas Indonesia. Vol 1(6): 1341 1347.

Ilhamdi M. L. (2018). Pola Penyebaran Capung (Odonata) Di Kawasan Taman Wisata Alam Suranadi Lombok Barat. J. biologi tropis, 18 (1) 
Koneri, R \& Saroyo (2011). Keanekaragaman KupuKupu (Lepidoptera) Pada Empat Tipe Habitat di Hutan Lindung Gunung Klabat, Sulawesi Utara. Biosfera, 28(2): 86 - 94.

Krebs C.J. (2009). Ecology: The Experimental Analysis of Distribution and Abundance (Sixth Edition). Pearson International Edition, USA.

Lamatoa, D. C., Koneri R., Siahaan R. \& Maabuat PV. (2013). Populasi kupukupu ( Lepidoptera ) di Pulau Mantehage, Sulawesi Utara. J. Ilm. Sains, 13 :52-56.

Lestari. Putri, R.D.A., Ridwan M. \&Purwaningsih, A.D. (2015). Keanekaragaman kupu-kupu (Insekta: Lepidoptera) di Wana Wisata Alas Bromo, BKPH Lawu Utara, Karanganyar, Jawa Tengah. Pros Sem Nas Masy Biodiv Indon, 1 (6): 1284-1288

Mittermeier R.A, Gil P.R \& Mittermeier C.G. (1997). Megadiversity: Earth's Biologically Wealthiest Nations. Agrupacion Sierra Madre

Noerdjito WA, Aswari P. 2003. Metode Survei dan Pemantauan Populasi Satwa: Seri Keempat Кири-kири Papilionidae. Bogor: Pusat Penelitian dan Pengembangan Biologi-LIPI Cibinong.

Nurjannah, ST. (2010). Biologi Troides helena helena dan Troides helena ephastus (Papilionidae) di Penangkaran.[Tesis]. Institut Pertanian Bogor.

Nugroho, I. S. (2017). Inventarisasi Keanekaragaman Jenis Kupu-Kupu (Lepidoptera) pada Berbagai Tipe Habitat di Taman Wisata Alam Suranadi. (Skripsi). Faperta, Universitas Mataram.

Peggie, J. \& M. Amir (2006). Panduan praktis kupukupu di Kebun Raya Bogor. Bidang Zoologi Puslit Biologi-LIPI dan Nagao Natural Environmental Foundation Jepang.

Rahadi, D., Syah, T. \& Tanaya, I.G.L.P. (2015). Analisis Strategi Pengelolaan Taman Wisata Alam Suranadi Kabupaten Lombok Barat Propinsi Nusa Tenggara Barat. Jurnal Ekosains, VII (2): 1 - 15

Rahayu, SE. \& Basukriadi, A. (2012). Kelimpahan dan Keanekaragaman Spesies Kupu-Kupu (Lepidoptera; Rhopalocera) Pada Berbagai Tipe Habitat di Hutan Kota Muhammad Sabki Kota Jambi. Biospecies, 5 (2) : $40-48$

Rohayuni (2002). Distribusi dan Keanekaragaman Diptera Di Hutan Wisata Suranadi Lombok
Barat Tahun 2002. Skripsi S1. Universitas Mataram.

Salmah S, Abbas I. \& Dahelmi (2012). Кири-кири Papilionidae di Taman Nasional Kerinci Seblat. KEHATI. Departemen Kehutanan. Taman Nasional Kerinci Seblat.

Sihombing, DTH. (2002). Satwa Harapan I: Pengantar Ilmu \& Teknologi Budidaya. Bogor. Pustaka Wirausaha Muda.

Soekardi, H. (2007). Кири-Кири Di Kampus Unila. Lampung. Universitas Lampung Press.

Suantara IN. (2000). Keragaman kupukupu (Lepidoptera) di Taman Nasional Gunung Halimun, Jawa Barat. [skripsi]. Institut Pertanian Bogor.

Sulistyani, T.H. (2013). Keanekaragaman JenisKupuKupu Lepidoptera: Rhopalocera DiKawasan Cagar Alam Ulolanang Kecubung Kabupaten Batang. Jurnal Bioekologi, 2 (1)

Septianella, G., Peggie, D. \& Sasaerila, H.Y. (2015). Keanekaragaman kupu-kupu (Lepidoptera) di kawasan Desa Pasirlangu, Kecamatan Cisarua, Kabupaten Bandung Barat, Jawa Barat. Pros Sem Nas Masy Biodiv Indon, 1 (8): 1816 1820.

Thomas, JA, Telfer, MG, Roy, DB, Preston, CD, Greenwood, JJD, Asher, J, Fox, R, Clarke, RT \& Lawton JH. (2004). Comparative Losses ofBritish Butterflies, Birds, and Plants and The Global Extinction, Science.

Vane-Wright RI \& de Jong R. (2003). The butterflies of Sulawesi : Annotated Checklist for a Critical Island Fauna. Zool Ver Leiden, 343: 3-267 